\title{
Peningkatan Aktivitas dan Hasil Belajar IPS Penyelesaian Masalah Lingkungan Sekitar Melalui Scientific Approach Siswa Kelas V SDN Lanjuk I Manding Sumenep
}

\author{
Sama' \\ Program Studi Pendidikan Guru Sekolah Dasar STKIP PGRI Sumenep \\ sultansamak@stkippgrisumenep.ac.id
}

\begin{abstract}
Abstrak
Penelitian ini di latarbelakngi oleh keterampilan dan kompetensi yang harus dikuasai oleh siswa masih sebatas pada keterampilan berpikir tingkat rendah dan hal itu membuat siswa belum mampu menyelesaikan permasalahan di lingkungan sekitarnya.Sehingga siswa tidak mampu mengembangkan potensinya. Model, metode dan media pembelajaran yang digunakan guru masih menggunakan pembelajaran yang terpusat pada guru, yaitu ceramah dan hanya fokus di dalam kelas. Konsep tersebut akan berdampak kepada hasil belajar siswa. Hal itu di buktikan dari observasi awal yang di lakukan oleh peneliti dengan kriteria ketuntasan minimal (KKM) yaitu 62 yang di tentukan oleh sekolah.dari jumlah seluruh siswa kelas V sebanyak 15 siswa, yang mencapai KKM hanya 5 siswa dengan presentase 33\%, sedangkan 10 siswa dengan persentase $67 \%$ belum mecapai KKM. Tujuan penelitian ini adalah untuk meningkatkan aktivitas dan hasil belajar IPS Siswa Kelas V SDN Lanjuk I. yang menjadi subjek dalam penelitian ini adalah seluruh siswa kelas V SDN Lanjuk I semester II tahun pelajaran 2017-2018 yang berjumlah 15 orang. Penelitian ini dilaksanakan pada bulan Februari sampai bulan Maret Tahun 2018. Instrumen pengumpulan data adalah lembar aktivitas siswa serta hasil tes belajar siswa. Penelitian ini menyajikan hasil observasi aktivitas dan hasil tes belajar yang diperoleh dari nilai observasi aktivitas siswa dan tes hasil belajar setiap siklus. aktivitas siswa diperoleh skor 27 dengan persentase 56,71\%.Siklus I aktivtas siswa rata-rata mencapai $60,41 \%$. Hasil belajar mencapai $60 \%$ dengan jumlah siswa yang tuntas sebanyak 9 orang. Pada siklus II aktivtas siswa rata-rata mencapai 74,26\%. Sedangkan hasil belajar mencapai 75 dengan jumlah siswa yang tuntas sebanyak 13 orang. Dengan demikian Pendekatan Saintifik dapat meningkatkan aktivitas dan hasil belajar IPS materi Penyelesaian masalah lingkungan sekitar Siswa kelas V SDN Lanjuk I Manding Sumenep.
\end{abstract}

Kata Kunci: Scientific Approah, aktivitas dan hasil belajar IPS, pembelajaran IPS. 


\section{PENDAHULUAN}

Era melenia semakin menuntut manusia untuk dapat mengikuti perkembangan di setiap pembaharuan yang sesuai perkembanganzaman. Keadaan yang demikian secara tidak langsung menuntut penddikan untuk dapat menghasilkan produk yang bisa bersaing dijaman modern. Pendidikan bisa dikatakan sebagai suatu kunci mensejahterakan bangsa dan negara. Pendidikan nasional bertujuan untuk meningkatkan kualitas manusia indonesia, yaitu manusia yang beriman dan bertaqwa terhadap Tuhan Yang Maha Esa, berbudi luhur, berkepribadian, mandiri, maju, tangguh, bertanggung jawab, dan produktif serta sehat jasmani dan rohani, menumbuhkan jiwa patriotik, dan mempertebal rasa cinta tanah air, meningkatkan semangat kebangsaan, dan kesetiakawanan sosial serta kesadaran pada sejarah bangsa dan sikap menghargai jasa para pahlawan, serta berorientasi ke masa depan. Menurut TAP MPR Nomor II/MPR/1993 (dalam Wahyudin, 2007:1).

Tujuan pendidikan di atas tentunya tidak lepas dari kompetensi guru yang menjadi tombak dalam proses pembelajaran. Secara umum, ada tugas guru sebagai profesi, yakni mendidik, mengajar dan melatih. Mendidik berarti meneruskan dan mengembangkan nilai- nilai hidup, mengajar berarti meneruskan dan mengembangkan ilmu pengetahuan, melatih berarti mengembangkan keterampilan-keterampilan untuk kehidupan siswa.

Menurut Suyanto DKK (2013:1) bahwa untuk dapat melaksanakan tugas dan tanggung jawab, seorang guru dituntut memiliki beberapa kemampuan dan kompetensi tertentu sebagai bagian dari profesionalisme guru. Ada beberapa kompetensi yang harus di miliki oleh guru, dianataranya kompetensi keperibadian, pedagogig, sosial dan profesional. Guru adalah fasilitator, guru sebaiknya mampu menumbuhkan minat belajar, menggugah rasa ingin tahu siswa, dan mendorong agar proses pembelajaran berlangsung dengan baik, dan menyenangkan

Proses pembelajaran di dalam kelas maupun di luar kelas di harapkan dapat membuat siswa merasa nyaman dan tidak tertekan, terlebih pada siswa sekolah dasar. Sekolah dasar merupakan sekolah tingkatan pertama siswa untuk mulai berfikir,di sekolah dasar terdapat kelas tinggi dan kelas rendah. Namun pada dasarnya siswa disekolah dasar masih identik dengan pemikiran yang kurang konkrit, selalu merasa ingin tahu hal-hal yang baru asing. Kegiatan pembelajaran dirancang untuk memberikan pengalaman belajar yang melibatkan proses mental 
Sama', Peningkatan Aktivitas dan Hasil Belajar IPS Penyelesaian Masalah Lingkungan Sekitar Melalui Scientific Approach...

dan fisik melalui interaksi antar siswa, siswa dengan guru, lingkungan, dan sumber belajar lainnya dalam rangka pencapaian kompetensi dasar. Belajar proses perubahan di dalam kepribadian yang berupa kecakapan, sikap, kebiasaan, dan kepandaian. Siswa sekolah dasar (SD) biasanya sulit untuk diajak belajar dengan cara ceramah melainkan harus secara praktek dalam lingkungan alam. Pembelajaran pada hakikatnya adalah suatu proses interaksi antara siswa dengan siswa, siswa dengan sumber belajar, dan dengan pendidik. Pembelajaran hendaknya mampu mengarahkan siswa terhadap realita, fakta, obyek, fenomena serta problematika yang dihadapinya dalam hidup keseharian khususnya pembelajaran IPS Pelajaran IPS sesuai dengan undang-undang Sisdiknas No.20 tahun 2003 adalah pelajaran yang wajib dimuat dalam kurikulum pendidikan dasar (KTSP). Istilah IPS mulai digunakan secara resmi di Indonesia sejak tahun 1975 (Ahmad Susanto, 2014: 7).

Pelajaran Ilmu Pengetahuan Sosial berbeda dengan mata pelajaran lainnya, pelajaran Ilmu Pengetahuan Sosial memberikan pembelajaran tentang konsep keadaan ilmu sosial untuk membantu siswa menjadi masyarakat yang profesional. Sehingga pelajaran Ilmu Pengetahuan Sosial harus mampu mengembangkan sikap sosial siswa terutama dalam mengembangkan sikap, nilai, dan mampu menyelesaikan permasalahan dalam lingkungan masyarakat. Pentingnya penguasaan keterampilan penyelesaian masalah sosial ini didasarkan pada; (1) perkembangan berpikir siswa yang seharusnya dapat berpikir secara kritis dan logis dalam menyelesaikan masalah, (2) kehidupan sehari-hari yang penuh dengan permasalahan sosial sangat membutuhkan penyeleasian secara cepat dan tepat, (3) keterlibatan siswa dalam masalah sosial yang terjadi di lingkungan daerah tempat siswa tinggal.

Dilihat dari Rencana Pelaksanaan Pembelajaran (RPP) yang dibuat oleh guru kelas V di SDN Lanjuk I diketahui indikator yang harus dicapai oleh siswa masih tergolong rendah. Keterampilan dan kompetensi yang harus dikuasai oleh siswa masih sebatas pada keterampilan berpikir tingkat rendah belum mampu menyelesaikan permasalahan di lingkungan sekitarnya. Sehingga siswa tidak mampu mengembangkan potensinya. Model, metode dan media pembelajaran yang digunakan guru masih menggunakan pembelajaran yang terpusat pada guru, yaitu ceramah dan 
hanya fokus di dalam kelas. Konsep tersebut akan berdampak kepada hasil belajar siswa. Hal itu di buktikan dari observasi awal yang di lakukan oleh peneliti dengan kriteria ketuntasan minimal (KKM) yaitu 65 yang ditentukan oleh sekolah dari jumlah seluruh siswa kelas V sebanyak 15 siswa, yang mencapai KKM hanya 5 siswa dengan presentase 33\%, sedangkan 10 siswa dengan persentase $67 \%$ belum mecapai KKM.

Mengkaji permasalahan di atas maka dibutuhkan solusi untuk mengatasinya. Solusi yang dapat membantu proses pembelajaran lebih bermakna, sehingga siswa dapat mengembangkan keterampilan penyelasian masalah social di lingkungannya. Masalah yang paling utama ialah guru belum menerapkan strategi pembelajaran yang tepat.

Untuk mengatasi masalah diatas guru dituntut harus lebih professional dan kreatif.dalam hal ini pendekatan saintifik sangat mampu mengatasi masalah tersebut. Menurut Nasution (2013:3) Pendekatan saintifik merupakan pendekatan pembelajaran yang berorientasi atau berpusat pada siswa (student centered approach). Pendekatan saintifik dapat melatih siswa untuk aktif dalam membangun pengetahuannya. Siswa yang memiliki rasa ingin tahu yang tinggi akan terwadahi dengan proses pendekatan saintifik. Hal ini sesuai dengan pengalaman siswa, bahwa dalam keidupan akan sering menjumpai sebuah permasalahan yang membutuhkan eksplorasi pengetahuan.

Menurut Rudolph (2005:363) menyatakan bahwa the scientific approach to problem solving across material and social domain. Sedangkan menurut Tang (2009:45) menyatakan bahwa scientific method is often thought as ordered step and that student can engage in scientific inquiry using everyday language, showing no evidence of being guided by those steps.

Pendekatan Saintifik sebagai upaya pembaharuan dalam pendekatan pembelajaran pada pelajaran IPS. Hal itu dikemukakan oleh Somantri (dalam Ahmad Susanto 2014:2), yaitu: a) bahan pelajaran lebih banyak memperhatikan kebutuhan dan minat anak, b) bahan pelajaran lebih banyak memperhatikan masalah-masalah sosial, c) bahan pelajaran lebih banyak memperhatikan keterampilan, khususnya keterampilan inquiry atau menyelidiki, dan d) bahan pelajaran lebih memberikan perhatian terhadap pemeliharaan dan pemanfaatan lingkungan alam sekitar. Pendekatan saintifik adalah proses yang dilalui siswa dalam rangka memperoleh sebuah jawaban, karena berpusat pada aktivitas 
Sama', Peningkatan Aktivitas dan Hasil Belajar IPS Penyelesaian Masalah Lingkungan Sekitar Melalui Scientific Approach...

siswa. Secara sederhana siswa dapat bertanya kepada orang-orang terdekatnya seperti orang tua. Siswa dengan tidak sadar telah bertanya dan berusaha mengumpulkan informasi.

Kemendikbud 2013 (dalam Atsnan, 2013:431) komponen pendekatan saintifik ada lima, yakni: mengamati, menanya, menalar, mencoba, dan mengkomunikasikan. Komponen tersebut akan dijelaskan secara mendetail berikut ini:

a. Mengamati

Mengamati merupakan kegiatan atau aktivitas siswa dalam melihat, mencermati, dan memeperhatikan dengan menggunakan alat indera.

b. Menanya

Menanya merupakan sifat alamiah siswa terhadap segala sesuatu yang sebelumnya belum pernah diketahui.

c. Mengumpulkan informasi
Mengumpulkan
informasi merupakan kegiatan mencari, menelaah, atau membaca informasi yang sesuai dengan materi pelajaran.
d. Mengasosiasikan/mengolah

Mengasosiasikan atau mengolah informasi adalah kegiatan mendata, manyatukan, memadukan, dan membandingkan informasi dengan kenyataan yang ada.

e. Mengkomunikasikan
Mengkomunikasikan dapat melatih siswa untuk berbicara, mempresentasikan atau menyampaikan hasil dari menjawab pertanyaan.

Serangkaian kegiatan dari mengamati, mengumpulkan informasi, mengolah, dan mengkomunikasikan merupakan kegiatan untuk melatih siswa memiliki karakter ilmiah. Tanpa disadari kegiatan yang telah diperoleh di sekolah akan diterapkan di lingkungan dimana siswa berada. Pengalam yang semakin bertambah banyak, akan mendorong siswa lebih aktif bertanya tentang hal-hal yang belum diketahuinya. Maka dari itu peneliti memilih Pendekatan Saintifik dalam pembelajaran IPS materi Penyelesaian Masalah Lingkungan Sekitar. 


\section{METODE}

Penelitian ini merupakan jenis penelitian tindakan kelas (Classroom Action Research). Menurut Arikunto (2014: 3), penelitin tindakan kelas merupakan suatu perencanaan terhadap kegiatan belajar berupa sebuah tindakan yang sengaja dimunculkan dan terjadidalam sebuah kelas secara bersama. Penelitian dilaksanakan di SDN Lanjuk I Manding Sumenep yaitu pada bulan Februari - Maret 2018. Subjek penelitian ini adalah siswa kelas V SDN Lanjuk I yang berjumlah 15 siswa, yang terdiri laki-laki 9 orang perempuan 6 orang.Penelitian ini dilaksanakan sebanyak dua siklus.

Alat pengumpulan data dalam penelitian ini ialah silabus, RPP dan LKS kemudian instrumen yang digunakan dalam pengumpulan data yaitu observasi aktivitas belajar siswa dan tes hasil belajar siswa. Data diperoleh melalui lembar pengamatan aktivitas siswa pada saat proses pembelajaran berlangsung dan tes hasil belajar IPS pada materi Penyelesaian Masalah Lingkungan Sekitar

Untuk mengetahui peningkatan aktivitas dan hasil belajar dari siswa setelah menerapkan pendekatan Saintifik, peneliti menganalisis data dengan menggunakan:

\section{Analisis data aktivitas siswa}

Menurut Sugiyono,

(2013:29)

bahwa aktivitas dalam analisis data yaitu dengan Display (Penyajian Data) dengan melalui penyajian data tersebut, maka data terorganisasikan, dan tersusun dalam pola hubungan, sehingga akan semakin mudah dipahami. Aktivitas siswa dikatakan efektif apabila siswa melakukan aktivitas pembelajaran setiap tahap dalam RPP. Kreteria keberhasilan aktivitas siswa dalam penelitian ini yaitu minimal $70 \%$ aktivitas pembelajran dilaksanakan oleh siswa, dengan rumus sebagai berikut :

$\mathrm{P}=\frac{F}{N} \times 100 \%$

Keterangan :

$\mathrm{P}=$ Persentase aktivitas

$\mathrm{F}=$ Jumlah sekor yang diperoleh

$\mathrm{N}=$ Jumlah maksimal semua komponen Adapun hasil observasi dipersentasikan dengan kreteria penilaian:

$81 \%-100 \%$ : sangat baik

$61 \%-80 \%$ : baik

$41 \%-60 \%$ : cukup

$21 \%-40 \%$ : kurang (Arikunto, 2006: 
Sama', Peningkatan Aktivitas dan Hasil Belajar IPS Penyelesaian Masalah Lingkungan Sekitar Melalui Scientific Approach...

\section{Analisis hasil belajar}

Analisis data hasil belajar siswa diperoleh dari hasil tes siswa. Tes tertulis setiap individu dihitung tiap instrumen soal tes pada pelajaran IPS materi permasalahan sosial di masyarakat bidang lingkungan.

Hasil tes diolah untuk mengetahui ketuntasan hasil belajar yang dicapai siswa, melalui rata-rata kelas dan ketuntasan belajar dengan rumus sebagai berikut:

\section{a. Rata-rata kelas}

$$
\mathrm{M}=\frac{\sum x}{N} \mathrm{x} 100 \%
$$

Keterangan

$\mathrm{M}$ : nilai rata-rat

$\sum x$ : jumlah semua nilai siswa

$N$ : jumlah siswa

\section{b. Ketuntasan belajar}

$$
\mathrm{P}=\frac{\sum x}{N} \times 100 \%
$$

Keterangan

P : persentase ketuntasan belajar

$\sum x:$ jumlah siswa yang mendapat nilai $\geq$ 70

$N$ : jumlah seluruh siswa

Hasil rata-rata belajar siswa secara klasikal yang diperoleh dikonvensikan dengan kreteria sebagai berikut:

$81 \%-100 \%$ : sangat baik
$61 \%-80 \% \quad$ : baik

$41 \%-60 \% \quad$ : cukup

$21 \%-40 \% \quad$ : kurang

$\leq 21 \% \quad$ : kurang sekali

\section{Indikator Keberhasilan Penelitian}

Penelitian ini dikatakan berhasil dalam proses pebelajaran apabila aktivitas siswa mencapai keberhasilan $\geq$ $70 \%$, dan apabila $\geq 70 \%$ siswa yang mencapai KKM 65. Sedangkan ketuntasan klasikal dikatakan tercapai apabila mencapai angka minimal 65\% dari seluruh siswa dalam kelas tersebut.

\section{HASIL DAN PEMBAHASAN}

Penelitian ini merupakan jenis penelitian tindakan kelas (Classroom Action Research) yang dilaksanakan di kelas V SDN Lanjuk I Manding Sumenep pada semester II Tahun Pelajaran 2017/2018 dengan jumlah siswa sebanyak 15 Siswa. Penelitian ini dilakukan dalam dua siklus. Masingmasing siklus terdiri dari satu kali pertemuan. Penelitian ini dilakukan oleh peneliti dibantu dengan Guru Kelas V di Sekolah SDN Lanjuk I yang bertindak sebagai observer.

Siklus I Perencanaan: Pada tahap ini peneliti menyiapkan instrumen penelitian yang terdiri dari perangkat pembelajaran yaitu Silabus, Rencana 
Pelaksanaan Pembelajaran, Lembar Kerja

Siswa dan Tes Hasil Belajar. Instrumen pengumpulan data yang digunakan adalah, Lembar observasi siswa, lembar tes hasil belajar.

\section{Pelaksanaan: Pelaksanaan} tindakan dilakukan sebanyak dua siklus. tindakan yang peneliti dilakukan adalah menerapkan Pendekatan Saintifik pada pembelajaran IPS dengan pelaksanaannya sebagai berikut : Pelaksanaan Pertama ( Hari Selasa, 20Februari 2018), pada tahap ini, peneliti mempersiapkan instrument. Pada tahap ini peneliti bertindak sebagai guru adapun proses belajar mengajar mengacu pada rencana pembelajaran yang telah dipersiapkan termasuk lembar Pengamatan (Obsevasi) yang di laksanakan dan juga pada saat pembelajaran berlangsung. Peneliti bekerjasama dengan Guru Kelas sebagai kolaborator melaksanakan pembelajaran IPS pada materi Penyelesaian Masalah Lingkungan Sekitar dengan menerapkanPendekatan Saintifik.

Observasi: Selama proses pembelajaran berlangsung menggunakan pendekatan Saintifik, Guru Kelas sebagai observer melakukan pengamatan terhadap aktivitas siswa. Pada siklus Isanagat terlihat bahwa siswa masih terlihat belum begitu semangat dan antusias dalam mengikuti proses pembelajaran.
Refleksi : Berdasarkan hasil diskusi Peneliti dan Guru Kelas sebagai observer, observer memberikan saran untuk siklus berikutnya peneliti lebih rinci, detai dan lebih menjelaskan lagi langkah-langkah pembelajaran dengan menggunakan Pendekatan Saintifik sehigga siswa tidak terlihat kebingungan dan asing dengan pendekatan yang digunakan oleh peneliti. Dari hasil refleksi tersebut diperoleh kesimpulan bahwa perlu adanya perbaikan lanjutan terhadap penerapan pendekatan saintifik, agar siklus II hasil yang diinginkan diperoleh lebih maksimal. Berdasarkan hasil refleksi pada siklus I, perencanaan dilakukan dengan memperbaiki Rencana Pelaksanaan Pembelajaran (RPP), LKS dan soal tes hasil belajar, agar supaya hasil belajar pada siklus II mencapai indikator ketuntasan yang di tentukan oleh sekolah.

Siklus II, Perencanaan: Pada perencanaan siklus II hampir sama dengan perencanaan pada siklus I. peneliti dengan guru kelas sebagai observer menentukan jadwal pelaksanaan siklus II.

Pelaksanaan: Pelaksanaan siklus II dilaksanakan sesuai dengan perencanaan yang telah dilakukan. Pelaksanaan pembelajaran siklus II dilaksanakan pada ( hariSelasa tanggal 13 Maret 2018. Pembelajaran dilakukan di 
Sama', Peningkatan Aktivitas dan Hasil Belajar IPS Penyelesaian Masalah Lingkungan Sekitar Melalui Scientific Approach...

dalam kelas dan di luar kelas yaitu lokasi lingkungan sekolah materi Penyelesaian Masalah Lingkungan Sekitar dan mengamati lingkungan sekitar sekolah.

Pelaksanaan pembelajaran siklus II meliputi lima komponen diantaranya mengamati, mengumpulkan informasi, mengolah, dan mengkomunikasikan. Adapun kegiatan yang dilakukan pada pertemuan pertama yaitu:Pada kegiatan awal guru membuka pelajaran dengan mengucapkan salam, berdoa dan mengecek kehadiran siswa. Guru kemudian menyampaikan apersepsi yang berhubungan dengan materi yang akan dipelajari hari ini. Guru memberikan pertanyaan untuk menggali kemampuan awal siswa. Siswa di beri kesempatan memikirkan jawaban. Kemudian siswa diminta untuk mengerjakan soal evaluasi untuk mengukur pemahama siswa terhadap materi pelajaran yang sudah dilaksanakan.

Observasi :Selama proses pembelajaran menggunakan pendekatan Saintifik, observer melakukan pengamatan terhadap aktivitas siswa. Pada siklus II terlihat bahwa siswa terlihat bersemengat dalam mengikuti proses pembelajaran.

Refleksi : Dari hasil observasi yang dilakukan guru sebagai observer, peneliti dan observer kembali melakuakan refleksi terhadap kegiatan pembelajaran yang dilakukan pada siklus II. Pembelajaran pada siklus II ini sudah lebih baik dari siklus I. Selama proses pembelajaran sudah berjalan dengan baik. Hal ini dapat dilihat dari lembar observasi aktivitas siswa dan hasil tes. Siswa juga sudah mulai aktif mengikuti proses pembelajaran sehingga peneliti menyimpulkan bahwa pada siklus II penelitian ini sudah mencapai kreteria keberhasilan.

\section{Aktivitas Siswa}

Berdasarkan observasi yang dilakukan dalam pelaksanaan pembelajaran maka dapat diketahui bahwa aktivitas yang dilakukan siswa sebagai berikut

Tabel 1. Hasil obsevasi aktivitas siswa siklus I, II

\begin{tabular}{|c|c|c|}
\hline & Siklus I & Siklus II \\
\hline Jumlah & 27 & 3 \\
\hline Persentase & $56,71 \%$ & $74,26 \%$ \\
\hline Katagori & Cukup & Sangat baik \\
\hline
\end{tabular}

Dari tabel 1 dapat disimpulkan secara umumobservasi siswa selama dua siklus dan secara keseluruhan aktivitas siswa dalam proses pembelajaran sudah meningkat dan nampak perubahan dari yang cukup menjadi sangat baik. Pada siklus I aktivitas siswa diperoleh skor 27 
Jurnal Pendidikan Modern. Volume 03 Nomor 03 Tahun 2018, 41-53

dengan persentase $56,71 \%$. Hal ini dapat dilihat dari peningkatan jumlah skor pada siklus II adalah sebesar 35 dengan persentase $74,26 \%$ katagori sangat baik Berdasarkan pada peningkatan persentase dari tabel diatas dapat di simpulkan bahwa proses pembelajaran dengan menggunakan pendekatan Saintifik dapat meningkatkan aktivitas siswa dalam proses pembelajaran.

\section{Hasil Belajar}

Guna mengetahui peningkatan hasil belajar siswa pada siklus I sampai siklus II dilakukan analisis terhadap hasil tes untuk mengetahui ketuntasan belajar secara individu dan klasikal. Adapun rekapitulasi hasil belajar siswa dapat dilihat pada tabel berikut :

Tabel. 2 Hasil Belajar Siswa siklus I, II dan III

\begin{tabular}{|c|c|c|}
\hline & Siklus I & Siklus II \\
\hline 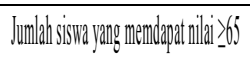 & 9 & 1 \\
\hline Persentase & $6 \quad 0 \%$ & $7 \quad 5 \%$ \\
\hline
\end{tabular}

Dari tabel di atas dapat dijelaskan bahwa Dari hasil skor dasar yang diperoleh, jumlah siswa yang mencapai nilai $\geq 65$ hanya berjumlah 9 orang atau $60 \%$ pada siklus I dan meningkat pada siklus II 13 orang atau $75 \%$

Berdasarkan uraian diatas dapat dilihat bahwa hasil belajar siswa semakin menigkat setelah menggunakan Pendekatan Saitifik. Berdasarkan data diatas dapat ditarik kesimpulan bahwa proses pembelajaran dengan menerapkan pendekatan Saintifik dapat meningkatkan aktivitas dan hasil bbelajar siswa. Hal ini sesuai dengan hipotesis dalam penelitian ini adalah : Penerapan Pendekatan Saintifik pada pelajaran IPS Penyelesaian Masalah Lingkungan Sekitar dapat meningkatkan Aktivitas dan Hasil Belajar Siswa Kelas V SDN Lanjuk I Kecamatan Manding Kabupaten Sumenep Tahun Pelajaran 2017-2018. 
Sama', Peningkatan Aktivitas dan Hasil Belajar IPS Penyelesaian Masalah Lingkungan Sekitar Melalui Scientific Approach...

PENUTUP

\section{Simpulan}

Berdasarkan analisis hasil penelitian dan pembahasan tentang penerapan Pendekatan Saintifikdalam meningkatkan aktivitas dan hasil belajar siswa pada mata pelajaran IPS materi Penyelesaian Masalah Lingkungan Sekitar kelas V SDN Lanjuk I Manding sumenep dapat diambil kesimpulan sebagai berikut:

1. Penerapan pembelajaran dengan pendekatan Saintifik dapat meningkatkan aktivitas belajar siswa dalam pembelajaran IPS materi Penyelesaian Masalah Lingkungan Sekitar kelas V SDN Lanjuk I Manding sumenep. Peningkatan tersebut dapat dilihat dari hasil siklus II yang sudah mencapai indikator keberhasilan penelitian ini. Penelitian dikatakan berhasil dalam proses pembelajaran apabila aktivitas siswa mencapai $\geq 70 \%$. Persentase rata-rata aktivitas siswa yang telah tercapai pada siklus II sebesar 74\%. hal ini berarti aktivitas siswa telah mengalami peningkatan yang signifikan.
2. Hasil belajar siswa kelas V SDN Lanjuk I pada Pelajaran IPS Materi Penyelesaian Masalah Lingkungan Sekitar dengan pendekatan Saintifik mengalami peningkatan secara signifikan. Peningkatan tersebut dapat dilihat dari hasil siklus II yang sudah mencapai indikator keberhasilan penelitian ini. Ketuntasan hasil belajar tercapai apabila nilai siswa mencapai KKM $\geq 65$ dan ketuntasan klasikal dikatakan tercapai apabila 75\% siswa sudah tuntas. 


\section{Saran}

Berdasarkan hasil penelitian yang telah dilakukan dengan menerapkan pendekatan Saintifikdalam pembelajaran IPS materi Penyelesaian Masalah Lingkungan Sekitar kelas V SDN Lanjuk I Manding Sumenep, maka saran yang ingin diberikan sebagai berikut :

1. Guru sebaiknya dalam pembelajaran IPS menggunakan pendekatan Saintifik. Berdasarkan penelitian yang sudah peneliti lakukan Pendekatan dapat meningkatkan aktivitas dan hasil belajar siswa.

2. Perlu dilakukan penelitian lanjutan terkait penerapan pendekatan Saintifik pada materi dan kontek yang lain.

\section{DAFTAR PUSTAKA}

Ahmat Susanto. (2014). Pengembangan Pembelajaran IPS di Sekolah Dasar. Jakarta: Prenada Media.

Nasution, Khairiah. (2013). Aplikasi Model Pembelajaran dalam Perspektif Pendekatan Saintifik. Makalah tidak dipublikasikan, Medan, Widyaswara Mandala tanggal 27 Desember 2013.
Rudolph, John L. (2005). Epistemology for the Mases: The Origins of "The Scientific Method" in American School. Volume 45 Number 3 pp. 341-376 Journal History of Education Quarterly 2005.

Tang, Xiaowei, Janet E. Coffey, Andy Elby, Danile M. Levin. (2009). The Scientific Method and Scientific Inquiry: Tensions in Teaching and Learning. Volume 94 Number 4 pp. 29-47 Journal Wiley Periodicals.Inc. 2008.

Atsnan, M.F, dan Gazali, Rahmita Yuliana. (2008). Penerapan Pendekatan Scientific dalam Pembelajaran Matematika SMP Kelas VII Materi Bilangan (Pecahan).Makalah disampaikan dalam Seminar Matematika Dan Pendidikan Matematika FMIPA, Yogyakarta, Universitas Negeri Yogyakarta tanggal 9 November 2013.

Arikunto, dkk. (2014). Penelitian Tindakan Kelas.Jakarta: Bumi Aksara.

Sugiyono. (2013). Metode Penelitian Pendidikan Pendekatan 
Sama', Peningkatan Aktivitas dan Hasil Belajar IPS Penyelesaian Masalah Lingkungan Sekitar Melalui Scientific Approach...

Kuantitatif, Kualitatif, dan

$R \& D$. Bandung: Alfabeta.

Suharsimi Arikunto. (2006). Prosedur

Penelitian Suatu Pendekatan

Praktik.Jakarta : PT Reneka

Cipta.

Wahyudin, dkk. (2007). Pengantar

Pendidikan. Jakarta:

Universitas Terbuka.

Suyanto dan Jihad. (2013). Menjadi Guru

Profesional. Jakarta: Erlangga. 